\title{
IGFBP2 is a biomarker for predicting longitudinal deterioration in renal function in type 2 diabetes
}

\author{
Ram P Narayanan', Bo Fu², Adrian H Heald ${ }^{1}$, Kirk W Siddals ${ }^{1}$, Robert L Oliver', \\ Julie E Hudson ${ }^{1}$, Antony Payton ${ }^{3}$, Simon G Anderson ${ }^{4}$, Anne White ${ }^{5}$, \\ William E R Ollier ${ }^{3,6}$ and J Martin Gibson ${ }^{1,7}$ \\ ${ }^{1}$ Vascular Research Group ${ }^{2}$ School of Community Based Medicine ${ }^{3}$ Centre for Integrated Genomic Medical Research \\ ${ }^{4}$ Cardiovascular Research Group ${ }^{5}$ Endocrinology and Diabetes, Faculty of Medical, Human and Life Sciences, \\ The University of Manchester, Manchester M13 9PT, UK ${ }^{6}$ Salford R\&D ${ }^{7}$ Department of Endocrinology and \\ Diabetes, Salford Royal Hospital NHS Foundation Trust, Salford M6 8HD, UK
}

Correspondence should be addressed to R P Narayanan B-202, Clinical Sciences Building, Salford Royal NHS Foundation Trust, Stott Lane, Salford

M6 8HD, UK

Email

ram.narayanan@manchester. ac.uk

\begin{abstract}
Objective: Insulin-like growth factors are implicated in the development of diabetic nephropathy. IGF-binding protein 2 (IGFBP2) and IGF2 are expressed in the kidney, but their associations with diabetic nephropathy are unclear. We therefore tested the hypothesis that circulating levels of IGF2 and IGFBP2 predict longitudinal renal function in individuals with type 2 diabetes. Design and methods: IGFBP2 and IGF2 measurements were performed in 436 individuals (263 males) with type 2 diabetes. Linear mixed-effect regression analysis was used to model the relationship between plasma IGFBP2 concentration and longitudinal changes in estimated glomerular filtration rate (eGFR) over an 8-year period. Analyses were also performed for IGF1, IGF2, IGFBP1 and IGFBP3 concentrations as predictors of longitudinal renal outcomes.

Results: High IGFBP2 concentration at baseline was associated with a decreased eGFR over an 8year period ( $\beta=-0.02$, (95\% confidence interval -0.03 to -0.01$), P<0.001)$. High IGFBP1, IGFBP2 and IGFBP3 were also associated with low baseline eGFR concentration. Conclusion: This study demonstrates that IGFBP2 is a predictor of longitudinal deterioration of renal function in type 2 diabetes.
\end{abstract}

Key Words

- IGFBP2

- longitudinal trends

- renal function

- real-world data

\section{Introduction}

The rising prevalence of diabetes worldwide is associated with increased morbidity and mortality (1). Diabetic nephropathy is a major complication of diabetes and is the commonest cause of end-stage renal disease (2). The development and progression of diabetic kidney disease is influenced by a number of biological factors. Among these, the insulin-like growth factor (IGF) family of proteins have been repeatedly implicated in the development of nephropathy and other complications of diabetes.

http://www.endocrineconnections.org

DOI: 10.1530/EC-12-0053
The IGF system comprises the two primary ligands, namely IGF1 and IGF2, six high-affinity fully characterised IGF-binding proteins (IGFBP1-IGFBP6) and the IGF receptors.

IGF1 and IGF2 are anabolic peptides with extensive structural and functional homology with insulin. They are ubiquitously expressed and play an indispensible role in the control of growth, proliferation and metabolism. IGF1 and IGF2 effect local and systemic responses through

C) 2012 The Authors. Published by BioScientifica Ltd. This is an Open Access article distributed under the terms of the Creative Commons Attribution License, which permits unrestricted use, distribution, and reproduction in any medium, provided the original author and source are credited. 
autocrine, paracrine and endocrine mechanisms. Both IGFs are expressed in the kidney, and rodent models have demonstrated renal expression of all six IGFBPs $(3,4)$.

A number of renal and systemic perturbations of the IGF system are known to occur in diabetic nephropathy (5). It has been speculated that IGF1-mediated increases of nitric oxide synthesis contribute to glomerular hyperfiltration in the early stages of diabetic kidney disease (6). IGF1 accumulates in the kidney soon after streptozotocin (STZ)-induced diabetes in rats and mice, but renal IGF1 expression is not usually increased, suggesting that the increased IGF1 is derived from the systemic circulation $(7,8)$. In contrast, both IGFBP1 renal expression and protein levels are elevated in mouse models of type 1 diabetes (8). One hypothesis is that in diabetic kidney disease there is an IGF-independent primary increase in IGFBP1 concentration in the kidney that subsequently traps IGF1 within the renal glomerulus. The sequestered IGF1 induces the glomerular hypertrophy and renal hyperfiltration that is characteristic of early diabetic nephropathy $(9,10)$.

Research with respect to the interactions of IGF2 in diabetic kidney disease has been limited. IGFBP2 has preferential affinity for IGF2 and is also widely expressed in the renal glomerulus (3). In this study, we used 'realworld' data to examine the hypothesis that concentrations of IGF2 and IGFBP2 at baseline were associated with longitudinal trends in glomerular filtration rate (GFR) in type 2 diabetes.

\section{Subjects and methods}

\section{Study population}

Four hundred forty-five individuals with type 2 diabetes were recruited from the city of Salford in north-west England. The city has $\sim 9100$ individuals with type 2 diabetes, and a representative sample was recruited from this background population for the Salford Longitudinal Diabetes Cohort. Approval was granted for this study by the Local Research Ethics Committee. Recruitment was undertaken in 2002-2003 from patients attending the diabetes outpatient clinics at the Salford Royal hospital for routine follow-up. Subjects who consented to participation donated a blood sample for circulating IGF protein measurements. Non-fasting blood samples were collected only at baseline. Access to longitudinal clinical measurements and drug prescription data was available from the Salford Integrated Records system which is a

http://www.endocrineconnections.org

DOI: 10.1530/EC-12-0053 comprehensive linked electronic dataset of primary care and hospital data.

\section{Laboratory methods}

Measurements of plasma IGF1, serum IGF2, plasma IGFBP1 (non-fasting), plasma IGFBP2 and plasma IGFBP3 were taken in the blood sample collected at study commencement.

IGF1 was measured using an Immulite $1000 \mathrm{immu}$ noassay (Siemens, Camberley, UK) with an analytical sensitivity of $20 \mathrm{ng} / \mathrm{ml}$ and within and inter-assay coefficients of variation $(\mathrm{CV})$ of $<4.5$ and $<8.4 \%$ respectively. IGF2 was measured using an ELISA developed using antibodies that have been previously reported (11). The analytical sensitivity of the assay was $<10 \mathrm{ng} / \mathrm{ml}$. The intra-assay and inter-assay sensitivities were $<6$ and $<10 \%$ respectively. IGFBP1 was measured using a locally developed assay that recognises all phosphoforms of IGFBP1 and has been reported in a previous study (12). This assay had inter-assay and intra-assay sensitivities of $<15$ and $<9 \%$, respectively, and the assay has an analytical sensitivity of $0.1 \mathrm{ng} / \mathrm{ml}$. IGFBP2 measurements were performed using the commercial RayBio Human IGFBP2 ELISA kit (RayBiotech, Inc., Norcross, GA, USA) with a manufacturer reported sensitivity of $<20 \mathrm{pg} / \mathrm{ml}$. The intra-assay CV for this assay was $<10 \%$ and the interassay CV was $<12 \%$. Plasma IGFBP3 was measured using the Immulite 1000 immunoassay that has an analytical sensitivity of $0.1 \mu \mathrm{g} / \mathrm{ml}$. The intra-assay CV for this assay was $<6 \%$ and the inter-assay CV was $<10 \%$.

Clinical and pharmacological data were obtained from a comprehensive linked database of primary and secondary care information related to the study patients. Measurements of serum creatinine, HbA1c, blood pressure, lipid profiles and all medication prescriptions for the years 2002-2009 were requested as a part of routine medical care by the subjects' health care providers. As all the study patients were recruited from the Salford area, the majority of blood tests was performed at the clinical laboratories of the local tertiary care hospital (Salford Royal NHS Foundation Trust). The last measurements of creatinine for each year between 2002 and 2009 in the health records were selected as representative for that year. Clinical and biochemical measurements for the year 2002 were used as baseline data.

Estimated GFR (eGFR) were calculated from serum creatinine measurements according to gender-specific modification of diet in renal disease (MDRD) equations (13). Serum creatinine measurements were performed

C) 2012 The Authors. Published by BioScientifica Ltd. This is an Open Access article distributed under the terms of the Creative Commons Attribution License, which permits unrestricted use, distribution, and reproduction in any medium, provided the original author and source are credited. 
using the Jaffe's method from 2002 to 2004 using the Roche Integra 700 Chemistry analyser, and from 2004 onwards using the Roche modular analyser. Changes in the diagnostic platforms for measurement of serum creatinine did not lead to changes in the normal reference ranges for these tests.

\section{Statistical analysis}

Statistical analysis was conducted using the software package Stata 10SE (College Station, TX, USA). Comparison of IGF proteins as well as baseline HbA1c, blood pressure, total cholesterol, LDL cholesterol, high-density lipoprotein (HDL) cholesterol and body mass index (BMI) in individuals with or without baseline eGFR $<60 \mathrm{ml} / \mathrm{min}$ per $1.73 \mathrm{~m}^{2}$ was made using independent samples $t$-tests. As measurements of IGF1, IGF2, IGFBP1, IGFBP2 and IGFBP3 were not normally distributed, their values were log-transformed for $t$-test purposes. All other variables studied followed a normal distribution.

Linear mixed-effect regression analysis was used to study the longitudinal trends in eGFR as outcomes of baseline serum IGF2 and plasma IGFBP2 concentrations, as well as plasma concentrations of other measured IGF proteins (IGF1, IGFBP1 and IGFBP3). Measurements of
eGFR followed a normal distribution. The IGF proteins were studied as predictors of eGFR at baseline and longitudinally. In each analysis, these levels were adjusted for the following covariates defined a priori: age, gender, baseline measurements of all IGF proteins, baseline measurements of BMI, systolic blood pressure and HbA1c, duration of diabetes at study commencement and the use of angiotensin-converting enzyme (ACE) inhibitors and angiotensin receptor blockers during the study period. Longitudinal analyses were additionally adjusted for time interaction. Measurements of creatinine, HbA1c, body weight and blood pressure from the year 2002 were considered baseline measurements. Baseline eGFR measurements were available for all patients.

\section{Results}

\section{The study population}

Of the total 445 study subjects in the Salford Longitudinal Diabetes Cohort, 267 were of male gender (60\%), and the mean age of the cohort was 62.8 years (95\% confidence interval (95\% CI) 61.8-63.8), 120 individuals had an eGFR $<60 \mathrm{ml} / \mathrm{min}$ per $1.73 \mathrm{~m}^{2}$ at study commencement; including nine individuals with an eGFR $<30 \mathrm{ml} / \mathrm{min}$

Table 1 Cardiovascular risk factor and medication profiles of study population at baseline and in 2009. Values expressed as arithmetic mean (S.D.).

\begin{tabular}{|c|c|c|}
\hline & Measurements in 2002 & Measurements in 2009 \\
\hline HbA1c (\%) & $8.0(1.6)$ & $11.8(13.2)$ \\
\hline $\mathrm{HbA} 1 \mathrm{c}(\mathrm{mmol} / \mathrm{mol})$ & 64 & 99 \\
\hline eGFR $\left(\mathrm{ml} / \mathrm{min}\right.$ per $\left.1.73 \mathrm{~m}^{2}\right)$ & $72(18)$ & $70(27)$ \\
\hline BMI $\left(\mathrm{kg} / \mathrm{m}^{2}\right)$ & $31.8(7.6)$ & $31.0(6.9)$ \\
\hline $\mathrm{BMI}>30 \mathrm{~kg} / \mathrm{m}^{2}(\%)$ & $55 \%$ & $49.2 \%$ \\
\hline Systolic BP (mmHg) & $138(18)$ & $134(20)$ \\
\hline Diastolic BP $(\mathrm{mmHg})$ & $75(11)$ & $71(10)$ \\
\hline Total cholesterol $(\mathrm{mmol} / \mathrm{l})$ & $4.6(0.9)$ & $3.9(0.9)$ \\
\hline HDL cholesterol $(\mathrm{mmol} / \mathrm{l})$ & $1.2(0.3)$ & $1.3(0.4)$ \\
\hline Percentage of subjects on ACE inhibitors or ARBs & 43.5 (in 2002) & $67.8(2002-2009)$ \\
\hline Percentage of subjects on anti-hypertensive medication & 54 (in 2002) & $79.6(2002-2009)$ \\
\hline Percentage of subjects on metformin & 58.5 (in 2002) & $80.3(2002-2009)$ \\
\hline Percentage of subjects on sulphonylureas & 36 (in 2002) & $61(2002-2009)$ \\
\hline Percentage of subjects on insulin & 29.5 (in 2002) & $43.3(2002-2009)$ \\
\hline Percentage of subjects on statins & 59 (in 2002) & 85.5 (2002-2009) \\
\hline
\end{tabular}

eGFR, estimated glomerular filtration rate by the modification of diet in renal disease equation; BMI, body mass index; BP, blood pressure; HDL, high-density lipoprotein; ACE, angiotensin-converting enzyme; ARB, angiotensin-2 receptor blocker.

http://www.endocrineconnections.org DOI: 10.1530/EC-12-0053
(C) 2012 The Authors. Published by BioScientifica Ltd. This is an Open Access article distributed under the terms of the Creative Commons Attribution License, which permits unrestricted use, distribution, and reproduction in any medium, provided the original author and source are credited. 
per $1.73 \mathrm{~m}^{2}$. These nine individuals with eGFR $<30 \mathrm{ml} / \mathrm{min}$ per $1.73 \mathrm{~m}^{2}$ were excluded from further analyses, and the remaining 436 individuals were analysed in this study.

The background characteristics of the 436 individuals remaining in the study at study commencement (2002) and at the end of the study (2009) are described in Table 1. Two hundred ninety-six subjects were identified to have been prescribed ACE inhibitors or angiotensin receptor blockers during the study period (2002-2009). Mean circulating concentrations of the measured IGF proteins expressed as geometric mean (95\% CIs) were as follows: IGF1, $125 \mathrm{ng} / \mathrm{ml}$ (120-130); IGF2, $569 \mathrm{ng} / \mathrm{l}$ (550-288); IGFBP1, 15 ng/ml (14-16); IGFBP2, 277 ng/ml (262-292) and IGFBP3, $4.2 \mathrm{mg} / \mathrm{l}(4.1-4.3)$.

Table 2 describes the baseline characteristics of subjects with eGFR above or below $60 \mathrm{ml} / \mathrm{min}$ per $1.73 \mathrm{~m}^{2}$ at study commencement. Three hundred twenty-five individuals had an eGFR $>60 \mathrm{ml} / \mathrm{min}$ per $1.73 \mathrm{~m}^{2}$ ('high eGFR') while the remaining 111 individuals had an eGFR below $60 \mathrm{ml} / \mathrm{min}$ per $1.73 \mathrm{~m}^{2}$ ('low eGFR'). Fifty-four (48.6\%) of the 'low eGFR' individuals were male. Mean age of the 'low eGFR' group was higher than the 'high eGFR' group $(P<0.0001)$, but interestingly the 'low
eGFR group' demonstrated a lower HbA1c level $(P=0.019)$ and a lower diastolic blood pressure $(P=0.018)$. Mean measurements of BMI, systolic blood pressure, total cholesterol and HDL cholesterol were similar in the two groups.

Concentrations of IGFBP1 (eGFR $>60 \mathrm{ml} / \mathrm{min}$ per $1.73 \mathrm{~m}^{2}$, mean $2.6 \mathrm{ng} / \mathrm{ml}$ (95\% CI 2.5-2.7); eGFR $<60 \mathrm{ml} / \mathrm{min}$ per $1.73 \mathrm{~m}^{2}, 2.9$ (95\% CI 2.7-3.1); $P=0.0009$ for log-IGFBP1) and IGFBP2 (eGFR $>60 \mathrm{ml} / \mathrm{min}$ per $1.73 \mathrm{~m}^{2}$, mean $5.5 \mathrm{ng} / \mathrm{ml}$ (95\% CI 5.4-5.6); eGFR $<60 \mathrm{ml} / \mathrm{min}$ per $1.73 \mathrm{~m}^{2}, 5.8$ (95\% CI $\left.5.7-5.9\right)$; $P<0.0001$ for log-IGFBP2) were higher in the low eGFR group $\left(<60 \mathrm{ml} / \mathrm{min}\right.$ per $\left.1.73 \mathrm{~m}^{2}\right)$ as compared with the high eGFR group. There was no significant difference in IGF1, IGF2 or IGFBP3 between the two groups. The box and whisker plots in Fig. 1 illustrate median IGFBP2 levels in the low and high eGFR groups.

Three patients developed end-stage renal disease (eGFR $<15 \mathrm{ml} / \mathrm{min}$ per $1.73 \mathrm{~m}^{2}$ ) during the study period. Two of these patients received haemodialysis, whereas one was treated conservatively. Of the 436 individuals (94\%), 409 were alive at study completion in 2009. Of the 27 deceased subjects, 23 belonged to the low eGFR group at baseline.

Table 2 Baseline characteristics of the study population grouped by glomerular filtration rate (GFR) above or below $60 \mathrm{ml} / \mathrm{min}$ per $1.73 \mathrm{~m}^{2}$ at study commencement. Clinical and biochemical characteristics of the study population at study commencement divided according to baseline estimated GFR as above or below $60 \mathrm{ml} / \mathrm{min}$ per $1.73 \mathrm{~m}^{2}$. Clinical variables described as arithmetic mean (s.D.) and IGF proteins expressed as median (interquartile range). Also described are $P$ values on independent sample $t$-test analysis of the two groups. IGF1, IGF2, IGFBP1, IGFBP2 and IGFBP3 log-transformed for $t$-test analyses.

\begin{tabular}{|c|c|c|c|}
\hline & eGFR above $60 \mathrm{ml} / \mathrm{min}$ per $1.73 \mathrm{~m}^{2}$ & eGFR below $60 \mathrm{ml} / \mathrm{min}$ per $1.73 \mathrm{~m}^{2}$ & $P$ value \\
\hline Age & $61.1(10.5)$ & $67.7(9.3)$ & $<0.0001$ \\
\hline $\mathrm{HbA1c}(\%)$ & $8.2(1.6)$ & $7.7(1.7)$ & 0.018 \\
\hline $\mathrm{HbA} 1 \mathrm{c}(\mathrm{mmol} / \mathrm{mol})$ & 66 & 61 & \\
\hline Body mass index $\left(\mathrm{kg} / \mathrm{m}^{2}\right)$ & $32.0(8.2)$ & $31.0(4.2)$ & 0.28 \\
\hline Systolic BP $(\mathrm{mmHg})$ & $137(17)$ & $141(20)$ & 0.08 \\
\hline Diastolic BP (mmHg) & $76(10)$ & $73(11)$ & 0.017 \\
\hline Total cholesterol $(\mathrm{mmol} / \mathrm{l})$ & $4.6(0.9)$ & $4.5(0.9)$ & 0.83 \\
\hline HDL cholesterol $(\mathrm{mmol} / \mathrm{l})$ & $1.2(0.3)$ & $1.2(0.3)$ & 0.73 \\
\hline IGF1 (ng/ml) & $125(64)$ & $135(87)$ & 0.08 \\
\hline IGF2 (ng/ml) & $584(266)$ & $617(238)$ & 0.22 \\
\hline IGFBP 1 (ng/ml) & $11(13)$ & $15(24)$ & 0.0009 \\
\hline IGFBP 2 (ng/ml) & $254(214)$ & $362(276)$ & $<0.0001$ \\
\hline IGFBP 3 (mg/l) & $4.3(1)$ & $4.3(1.9)$ & 0.34 \\
\hline
\end{tabular}

BP, blood pressure; HDL, high-density lipoprotein; IGF, insulin-like growth factor; IGFBP, IGF-binding protein.

http://www.endocrineconnections.org

DOI: 10.1530/EC-12-0053
(C) 2012 The Authors. Published by BioScientifica Ltd. This is an Open Access article distributed under the terms of the Creative Commons Attribution License, which permits unrestricted use, distribution, and reproduction in any medium, provided the original author and source are credited. 


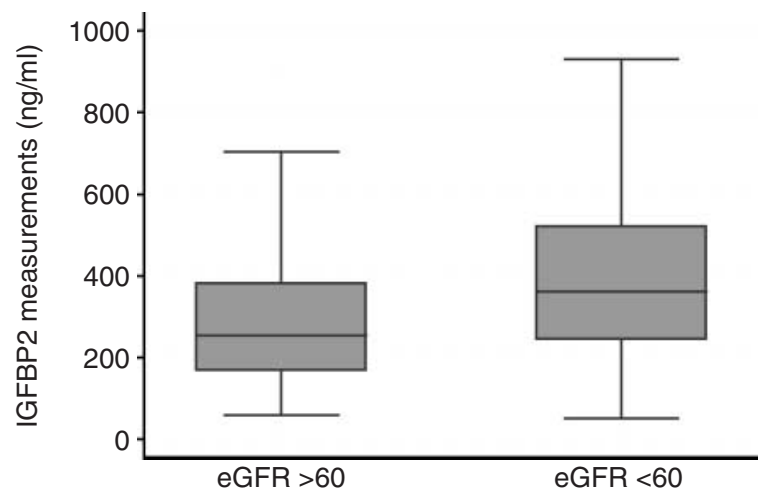

Figure 1

Box-plot representing plasma IGFBP2 concentration $(\mathrm{ng} / \mathrm{ml})$ in the study population classified according to baseline estimated glomerular filtration rate as above or below $60 \mathrm{ml} / \mathrm{min}$ per $1.73 \mathrm{~m}^{2}$. Horizontal line in the centre represents median IGFBP2 in each group, and box represents the interquartile ranges. Ends of whiskers indicate 5th and 95th percentiles. Outlying values not represented.

\section{IGF proteins and baseline GFR}

Each of the IGF proteins was studied individually as a predictor of baseline eGFR, with the study model adjusted for age, gender, diabetes duration, baseline measurements of systolic blood pressure, $\mathrm{HbA1c}$ and BMI, and the use of ACE inhibitors or angiotensin receptor blockers at study commencement as covariates.

High IGFBP2 concentration was associated with a low baseline eGFR in the analysis $(\beta=-0.02$ (95\% CI -0.03 to -0.01$), P<0.001)$. High IGFBP1 was also associated with low baseline GFR $(\beta=-0.12(95 \%$ CI -0.19 to $-0.05), P=0.001)$. IGF1 $(P=0.26)$, IGF2 $(P=0.94)$ and IGFBP3 $(P=0.29)$ were not associated with baseline eGFR. When all the five measured IGF proteins were taken together in the previous linear regression model, associations of eGFR with IGFBP1 $(\beta=-0.09(95 \% \mathrm{CI}-0.17$ to $-0.02), P=0.008)$ and IGFBP2 $(\beta=-0.02$ (95\% CI -0.03 to -0.01$), P<0.001)$ were sustained, and high IGFBP3 was also associated with low eGFR $(\beta=-2.4$ (95\% CI -4.2 to -0.53$), P=0.012$ ).

\section{IGF proteins and longitudinal renal function trends}

Associations of IGF proteins with longitudinal trends in eGFR were analysed in mixed-effects regression models adjusted for age, gender, diabetes duration at study commencement, measurements of IGF1, IGF2, IGFBP1, IGFBP2 and IGFBP3, baseline concentrations of BMI, HbA1c and systolic blood pressure, and the use of ACE

http://www.endocrineconnections.org

DOI: 10.1530/EC-12-0053 inhibitors or angiotensin receptor blockers during the study period.

High IGFBP2 at baseline was associated with a decreased eGFR over an 8-year period from 2002 to 2009 $(\beta=-0.02(95 \% \mathrm{CI}-0.03$ to -0.01$), P<0.001)$ in the above study model. Figure 2 illustrates mean eGFR values for each of the years from 2002 to 2009 according to quartiles of baseline IGFBP2. IGF1 $(P=0.71)$, IGF2 $(P=0.69)$, IGFBP1 $(P=0.18)$ and IGFBP3 $(P=0.17)$ were not associated with longitudinal eGFR trends in this study model.

\section{Conclusion}

This study reports associations of high baseline IGFBP2 with adverse forward trends in renal function in type 2 diabetes. We found elevated IGFBP2 concentration to be associated with a longitudinal decline in GFR and an increase in proteinuria in Caucasians with type 2 diabetes.

IGFBP2 is the second most abundant circulating IGFBP (14), and has a greater affinity for IGF2 over IGF1 (15). Like other IGFBPs, it exerts biological effects that are both dependent on and independent of IGF1 and IGF2 $(16,17,18)$. IGFBP2 concentrations correlate with insulin sensitivity, and low levels of this protein are a marker for the metabolic syndrome $(19,20,21)$.

In the kidney, IGFBP2 expression has been demonstrated in the renal glomerulus, thin limbs of the loop of Henle and medullary collecting ducts, and may play an important role in renal podocyte development and maturation $(3,4,22,23,24)$. IGFBP2 is preferentially expressed in the glomerulus, similar to the other IGFBPs: IGFBP1, IGFBP4 and IGFBP5. A study on STZ-induced diabetes rats indicated that renal mesangial concentrations of IGFBP2 and IGF2 are significantly increased early in the course of diabetes, along with local concentrations of IGF1 and IGFBP1 (25). However, other studies in STZ-diabetes rats have not demonstrated increased renal IGFBP2 mRNA levels in this model of diabetic nephropathy $(9,26,27)$.

Previous studies have reported increased IGFBP2 concentrations in chronic renal failure (28). Poor glycaemic control in type 1 diabetes was associated with increased IGFBP2 proteolysis in albuminuric subjects (29). Associations of IGFBP2 with longitudinal trends in renal function have not been previously reported.

IGF2 is a major regulator of embryonic growth and development. While its postnatal roles have not been adequately clarified, it circulates at concentrations higher than that of IGF1.

() 2012 The Authors. Published by BioScientifica Ltd. This is an Open Access article distributed under the terms of the Creative Commons Attribution License, which permits unrestricted use, distribution, and reproduction in any medium, provided the original author and source are credited. 


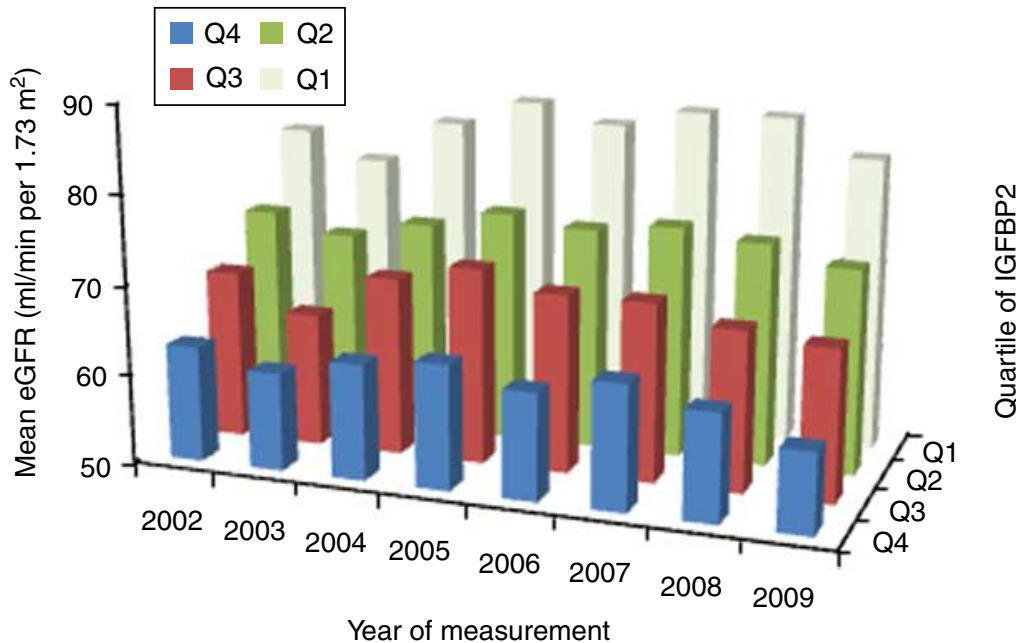

Figure 2

Graph representing yearly mean estimated glomerular filtration rates (eGFR) for the years 2002-2009 according to quartiles of baseline IGFBP2.

IGF2 mRNA is widely expressed in renal tissue. Transgenic mice overexpressing IGF2 demonstrate increased renal size (30). A study in STZ-induced diabetes rats reported an increase in serum and kidney IGF2 concentrations after the onset of diabetes, but without an increase in renal IGF2 mRNA expression (31). This would suggest that the increased renal IGF2 concentration was derived from the systemic circulation rather than produced within the kidney itself.

In a study that compared individuals with nondiabetic chronic kidney disease subjects with healthy controls, Frystyk et al. (32) reported significant increases in total serum IGF2 as well as IGFBP1 and IGFBP2 in those with nephropathy.

Glomerular hypertrophy is observed quite early in the pathophysiology of diabetic nephropathy. It is possible that an increase in IGFBP2 concentrations occurs in type 2 diabetes followed by an increase in local IGF1 and IGF2 concentrations in the renal glomerulus, very similar to the hypothesis postulated for IGF1 and IGFBP1 interaction in nephropathy. Given the affinity of IGFBP2 for IGF2, it may facilitate renal IGF1 and IGF2 accumulation. Longitudinal measurements of renal and systemic concentrations of IGF2 and IGFBP2 in diabetes and diabetic nephropathy will be needed to clarify which of these potential mechanisms results in the independent relation between higher circulating IGFBP2 and more adverse renal outcome over time.

http://www.endocrineconnections.org

DOI: 10.1530/EC-12-0053
Our study had some limitations. Being an observational 'real-world' study with clinical and biochemical tests instigated by the patients' usual healthcare providers, it was inevitable that investigations had not been performed on every patient annually. As albumincreatinine ratios had not been measured in a number of patients (especially in the early years of the study), we have not reported associations of the IGF proteins with baseline and longitudinal trends in proteinuria. Some of the blood samples were collected from non-fasting subjects, which may have partly affected the results of analyses involving IGFBP1 (though IGFBP2 concentration is not affected by $<72 \mathrm{~h}$ of fasting, and other IGF protein concentrations are also unaffected). Ideally we would have liked to measure IGF proteins at another time point to assess the change in IGF protein concentration in relation to changes in eGFR. While our study was aimed at a population with type 2 diabetes, it would be interesting to study whether the associations of IGFBP2 with eGFR are also true of a non-diabetic study population.

In summary, we report that IGFBP2 is a marker for deterioration in renal function in Caucasians with type 2 diabetes. The cellular activities of IGFBP2 in the kidney may have significant implications in diabetic nephropathy and research is required to elucidate whether there is a causative relationship between circulating IGFBP2 and progression of renal disease.

() 2012 The Authors. Published by BioScientifica Ltd. This is an Open Access article distributed under the terms of the Creative Commons Attribution License, which permits unrestricted use, distribution, and reproduction in any medium, provided the original author and source are credited. 


\section{Declaration of interest}

The authors declare that there is no conflict of interest that could be perceived as prejudicing the impartiality of the research reported.

\section{Funding}

This research did not receive any specific grant from any funding agency in the public, commercial or not-for-profit sector.

\section{Author contribution statement}

R P Narayanan was involved in the design of the study, data collection and interpretation, and writing of the manuscript. B Fu assisted with the statistical analysis. A White provided antibodies for the IGF2 assay and reviewed the manuscript. K W Siddals, $\mathrm{R} L$ Oliver and J E Hudson performed the IGFBP1, IGFBP3, IGF1 and IGF2 assays. A Payton and WE R Ollier reviewed the manuscript. S G Anderson contributed to discussions. A H Heald was involved in the study design and reviewing the manuscript. J M Gibson was involved in study design and is the overall guarantor of the study.

\section{Acknowledgements}

The authors wish to acknowledge the assistance of the Manchester Academic Health Science Centre and the Salford Royal Hospital NHS Foundation Trust for facilitating this study and North West e-health, Manchester for assistance with data extraction. This study has been presented as an abstract at the Association for Clinical Biochemistry meeting at Liverpool, UK in May 2012.

\section{References}

1 Whiting DR, Guariguata L, Weil C \& Shaw J. IDF diabetes atlas: global estimates of the prevalence of diabetes for 2011 and 2030. Diabetes Research and Clinical Practice 201194 311-321. (doi:10.1016/j.diabres. 2011.10.029)

2 USRDS. United States Renal Data System 2011 Annual Data Report: Atlas of End-Stage Renal Disease in the United States. National Institutes of Health, National Institute of Diabetes and Digestive and Kidney Diseases, Bethesda, 2011. (www.usrds.org)

3 Fujinaka H, Katsuyama K, Yamamoto K, Nameta M, Yoshida Y, Yaoita E, Tomizawa S \& Yamamoto T. Expression and localization of insulin-like growth factor binding proteins in normal and proteinuric kidney glomeruli. Nephrology 201015 700-709. (doi:10.1111/j.1440-1797. 2010.01285.x)

4 Price GJ, Berka JL, Edmondson SR, Werther GA \& Bach LA. Localization of mRNAs for insulin-like growth factor binding proteins 1 to 6 in rat kidney. Kidney International 199548 402-411. (doi:10.1038/ki.1995. 308)

5 Cingel-Ristic V, Flyvbjerg A \& Drop SLS. The physiological and pathophysiological roles of the GH/IGF-axis in the kidney: lessons from experimental rodent models. Growth Hormone \& IGF Research 2004 14 418-430. (doi:10.1016/j.ghir.2004.06.003)

6 Levin-Iaina N, Iaina A \& Raz I. The emerging role of NO and IGF-1 in early renal hypertrophy in STZ-induced diabetic rats. Diabetes/Metabolism Research and Reviews 201127 235-243. (doi:10.1002/dmrr.1172)

7 Flyvbjerg A, Bornfeldt KE, Marshall SM, Arnqvist HJ \& Orskov H. Kidney IGF-I mRNA in initial renal hypertrophy in experimental diabetes in rats. Diabetologia 199033 334-338. (doi:10.1007/BF00404636)

8 Segev Y, Landau D, Marbach M, Shehadeh N, Flyvbjerg A \& Phillip M. Renal hypertrophy in hyperglycemic non-obese diabetic mice is associated with persistent renal accumulation of insulin-like growth factor I. Journal of the American Society of Nephrology 19978 436-444.

http://www.endocrineconnections.org

DOI: $10.1530 /$ EC-12-0053
9 Park IS, Kiyomoto H, Alvarez F, Xu YC, Abboud HE \& Abboud SL. Preferential expression of insulin-like growth factor binding proteins-1, -3 , and -5 during early diabetic renal hypertrophy in rats. American Journal of Kidney Diseases 199832 1000-1010. (doi:10.1016/S02726386(98)70075-7)

10 Miyatake N, Shikata K, Wada J, Sugimoto H, Takahashi S \& Makino H. Differential distribution of insulin-like growth factor-1 and insulin-like growth factor binding proteins in experimental diabetic rat kidney. Nephron 199981 317-323. (doi:10.1159/000045299)

11 Crosby SR, Anderton CD, Westwood M, Holly JM, Cwyfan Hughes SC, Gibson M, Morrison CA, Young RJ \& White A. Measurement of insulinlike growth factor-II in human plasma using a specific monoclonal antibody-based two-site immunoradiometric assay. Journal of Endocrinology 1993137 141-150. (doi:10.1677/joe.0.1370141)

12 Stephens RH, McElduff P, Heald AH, New JP, Worthington J, Ollier WE \& Gibson JM. Polymorphisms in IGF-binding protein 1 are associated with impaired renal function in type 2 diabetes. Diabetes $2005 \mathbf{5 4}$ 3547-3553. (doi:10.2337/diabetes.54.12.3547)

13 Levey AS, Bosch JP, Lewis JB, Greene T, Rogers N \& Roth D. A more accurate method to estimate glomerular filtration rate from serum creatinine: a new prediction equation. Modification of Diet in Renal Disease Study Group. Annals of Internal Medicine 1999130 461-470.

14 Clemmons DR, Snyder DK \& Busby WH Jr. Variables controlling the secretion of insulin-like growth factor binding protein-2 in normal human subjects. Journal of Clinical Endocrinology and Metabolism 1991 73 727-733. (doi:10.1210/jcem-73-4-727)

15 Shimasaki S \& Ling N. Identification and molecular characterization of insulin-like growth factor binding proteins (IGFBP-1, -2, -3, -4, -5 and -6). Progress in Growth Factor Research 19913 243-266. (doi:10.1016/ 0955-2235(91)90003-M)

16 Russo VC, Bach LA, Fosang AJ, Baker NL \& Werther GA. Insulin-like growth factor binding protein-2 binds to cell surface proteoglycans in the rat brain olfactory bulb. Endocrinology 1997138 4858-4867. (doi:10.1210/en.138.11.4858)

17 Moore MG, Wetterau LA, Francis MJ, Peehl DM \& Cohen P. Novel stimulatory role for insulin-like growth factor binding protein-2 in prostate cancer cells. International Journal of Cancer 2003105 14-19. (doi:10.1002/ijc.11015)

18 Rorive S, Berton A, D'Haene N, Takacs CN, Debeir O, Decaestecker C \& Salmon I. Matrix metalloproteinase-9 interplays with the IGFBP2-IGFII complex to promote cell growth and motility in astrocytomas. Glia 200856 1679-1690. (doi:10.1002/glia.20719)

19 Hedbacker K, Birsoy K, Wysocki RW, Asilmaz E, Ahima RS, Farooqi IS \& Friedman JM. Antidiabetic effects of IGFBP2, a leptin-regulated gene. Cell Metabolism 201011 11-22. (doi:10.1016/j.cmet.2009.11.007)

20 Heald AH, Kaushal K, Siddals KW, Rudenski AS, Anderson SG \& Gibson JM. Insulin-like growth factor binding protein-2 (IGFBP-2) is a marker for the metabolic syndrome. Experimental and Clinical Endocrinology \& Diabetes 2006114 371-376. (doi:10.1055/s-2006-924320)

21 Arafat AM, Weickert MO, Frystyk J, Spranger J, Schofl C, Mohlig M \& Pfeiffer AFH. The role of insulin-like growth factor (IGF) binding protein-2 in the insulin-mediated decrease in IGF-I bioactivity. Journal of Clinical Endocrinology and Metabolism 200994 5093-5101. (doi:10.1210/jc.2009-0875)

22 Bridgewater DJ \& Matsell DG. Insulin-like growth factor binding protein-2 modulates podocyte mitogenesis. Pediatric Nephrology 2003 18 1109-1115. (doi:10.1007/s00467-003-1242-x)

23 Lindenbergh-Kortleve DJ, Rosato RR, van Neck JW, Nauta J, van Kleffens M, Groffen C, Zwarthoff EC \& Drop SL. Gene expression of the insulin-like growth factor system during mouse kidney development. Molecular and Cellular Endocrinology 1997132 81-91. (doi:10.1016/S0303-7207(97)00123-8)

24 Chin E, Michels K \& Bondy CA. Partition of insulin-like growth factor (IGF)-binding sites between the IGF-I and IGF-II receptors and IGF-binding proteins in the human kidney. Journal of Clinical Endocrinology and Metabolism 199478 156-164. (doi:10.1210/jc.78.1.156)

() 2012 The Authors. Published by BioScientifica Ltd. This is an Open Access article distributed under the terms of the Creative Commons Attribution License, which permits unrestricted use, distribution, and reproduction in any medium, provided the original author and source are credited. 
25 Han HJ, Kang CW \& Park SH. Tissue specific regulation of insulin-like growth factors and insulin-like growth factor binding proteins in vitro and in vivo. Clinical and Experimental Pharmacology \& Physiology 200633 1172-1179. (doi:10.1111/j.1440-1681.2006.04495.x)

26 Fervenza FC, Tsao T, Hoffman AR \& Rabkin R. Regional changes in the intrarenal insulin-like growth factor-I axis in diabetes. Kidney International 199751 811-818. (doi:10.1038/ki.1997.114)

27 Price GJ, Berka JL, Werther GA \& Bach LA. Cell-specific regulation of mRNAs for IGF-I and IGF-binding proteins-4 and -5 in streptozotocindiabetic rat kidney. Journal of Molecular Endocrinology 199718 5-14. (doi:10.1677/jme.0.0180005)

28 Tonshoff B, Blum WF \& Mehls O. Serum insulin-like growth factors and their binding proteins in children with end-stage renal disease. Pediatric Nephrology 199610 269-274. (doi:10.1007/BF00866755)

29 Akinci A, Copeland KC, Garmong A \& Clemmons DR. Insulin-like growth factor binding proteins (IGFBPs) in serum and urine and
IGFBP-2 protease activity in patients with insulin-dependent diabetes mellitus. Metabolism: Clinical and Experimental 200049 626-633. (doi:10.1016/S0026-0495(00)80039-6)

30 Wolf E, Kramer R, Blum WF, Foll J \& Brem G. Consequences of postnatally elevated insulin-like growth factor-II in transgenic mice: endocrine changes and effects on body and organ growth. Endocrinology 1994135 1877-1886. (doi:10.1210/en.135.5. 1877)

31 Han HJ \& Park SH. Alteration of the gene and protein levels of insulinlike growth factors in streptozotocin-induced diabetic male rats. Journal of Veterinary Medical Science 200668 413-419. (doi:10.1292/ jvms.68.413)

32 Frystyk J, Ivarsen P, Skjaerbaek C, Flyvbjerg A, Pedersen EB \& Orskov H Serum-free insulin-like growth factor I correlates with clearance in patients with chronic renal failure. Kidney International 199956 2076-2084. (doi:10.1046/j.1523-1755.1999.00798.x)

Received in final form 21 August 2012

Accepted 19 September 2012 